\title{
Fraud Evaluation in Public Management: Legal Aspects of Engineering
}

\author{
Fábio Marcio Bisi Zorzal* and Sergio João Ferreira Lievore \\ Enseada do Suá, Vitória-ES, Brazil
}

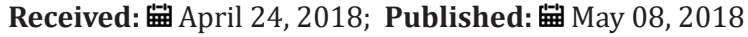

*Corresponding author: Fábio Marcio Bisi Zorzal, Rua José Alexandre Buaiz, 157, Enseada do Suá, Vitória-ES, Brazil, Tel: 27 3334-7600; Email: fabio.zorzal@tce.es.gov.br

Keywords: Fraud evaluation; Legal aspects of engineering; Public works auditing; Findings and irregularities; Accountability

\section{Introduction}

Fraud is seen as a potential element when adorning administrative and judicial processes Jarzembski [1]. However, it is only a way to achieve the wrongful act, peaceful subterfuge, a hiding place for what would be a bigger misconduct. Sometimes, however, it requires continuity of the act in order to not be caught, often exceeding its original purpose. If there are conditions, motivation and attitude Loebbeck et al. [2] it perseveres in the addiction that breaks the time, requiring bitter medicines when disfigure the ordinary character of those who are innocuous. Treating a fraud would be more of a classic law or accounting action, but here is presented a captive engineering case study of a long administrative process in The Brazilian Federal Court of Accounts, TCU, dragged for over a decade, which is why it comes as a protagonist in the academic and scientific sphere, which has no link with practice, or even affects the authority of these audit and regulatory professionals Francis [3].

In the real field, this process snatched the energies of the technical area to the fulfill its duty according to what would be analyze the legal defence up to the initial accusation, in the strenuous contradictory practice that insults the sense of their higher purpose. In opposition, the defence uses a confusion strategy in a broad sense, sometimes with documents out of the regiment, tolerated by a system that extremely favours the defence, using the time to tire others, where the clumsy actions could make the legacy disappear, but achieve it by punitive prescription, something to be expected from those who value the professional practice. On the other hand, however, the State finds itself in a complex way of applying the force of law, admitting no deviations, otherwise it would be used in favour of the immoral and illegal ones, in other words, and it is not worth using the same traps of those who defraud.
In this context, from a conclusive piece of engineering produced by the technical department of the Court, finishing a late case remaining from a time still alive in The Brazilian Administrative Courts, could be loaned to any other case in obvious extrapolation. This mirrored picture here should be used as a way to add maturity to sister institutions, and as an example to do not give up on this trajectory seen by society. This is one of the active lines in tackling white-collar crimes intentionally exercised in legitimate institutions Gottschalk [4] in the present time giving up the real legal meaning that compensation can still be used as correction. Even under certain limitations, it is the republican form of bleeding, but weed out the parasites that wield political and economic power in the perpetual impunity.

The Brazilian legal system denies barriers that greatly favour the defendant, two of which should be highlighted:

(i) Whether the defendant could lie in your favour; or at least do not force himself to tell the truth.

(ii) The multiplicity of appellate instances, sometimes in parallel with justice, which dissipates the regimental course of the administrative process at a slow rhythm, a known way by lawyers who dictating the defence compass considering the possibilities that leads to endless discussions. Paradigm of this deal, this is a treaty that can be used as a model to deface the strategies, tactics and rhythmic operations in time for dark purposes, limiting to the scope of the Court of Accounts on public management, its main objective, while limited to the technical area of engineering.

As the result of administrative confusion, often subsidizing lawsuit in the fraud approach, which is context of the (I) introduction, 
there is enough reason to this work establishes some concepts, One (II) review of the literature used to distinguish the nature of documentary records and technical parts, discussing the evidence and technical welfare. In a subsidiary way, it shows irregularities translated into the legal framework criteria, compared to the characterization of fraud in the observation of cases. Therefore, it is possible to bring the defence argument in the typical conduct of adversarial exercise to impound accountability and typifying suppressors when they exist. In this context, it is possible to recognize the mismanagement and its relative treatment, where the route is designed for the plot in this theoretical front, the model that is sought.

After this review, here is presented the (III) methodology used to demonstrate their applicability. In fact, it is an intense and deep engineering work that runs a broad thematic spectrum of works and services of construction, including on an emergency basis, also waste collection and transportation, among other topics that require more than attention and breath, they require knowledge and coping. Therefore, it confronts various contracts and discusses the design works and engineering services from design to implementation, inquiring technological results provided by trials that confront normative instructions and service specifications, surpluses (sizing) in their quantities and prices according to overvalued pricesal ready practiced, as well as quality aspects, in terms of fitness for use. Moreover, it has been taken into discussion the renegotiation and illegal adjustments in contracts.

It is presented in the form of (IV) case studies that build and support the purposeful convention to see the works and engineering services as a generalization, connected to the predatory modus operandi. The first one comes from a set of contracts that replicate its scope as if they had never been done, known as the double effect. Then, a group of contracts manipulating spread sheets and compensation, called 'chemical', at the apex of the defences, including concealment of services. Moreover, it was observed illegal renegotiation and readjustment scaled up to overpricing without depleting these indeed a rich diversity of problems in which it can work in the exploratory field of the case study, aiming on creating a fraud evaluation model.

This allowed the expansion of the discussion of fraud in a procedural pragmatism, emphasizing its approach to appreciation of the scientific and professional community, derived from innovative relevance to what is ultimately possible to establish the (V) conclusions and final considerations of the work, suggesting the improvement of the monitoring processes and control of projects through audits and punishment in the subsequent trial of these causes, which is not the focus of this work.

\section{Literature Review}

The administrative or judicial process is a document made up of different parts, result of the manifestation of the parts that influence the judge in the form of its subsequent reviews, which weight of impartiality should set the tone of the measure of the decision. The first pieces that add up usually have the accusatory tone, found the relevance of audit findings from the external control activity and other related procedural mechanisms, and do not dismiss the allegations promoted by social control. They are followed by other parts of defensive connotation submitted after the citation of charge, analyzing the same procedural tools provided. In countries that follow the standards INTOSAI Guidance for Good Governance Blegvad [5] the judgment is usually preceded by the technical opinion of experts, ranging in depth that each case deserves, based on adapted government auditing standards, despite the experience of the auditors always innovating the specific work plans Cormier \& Lapointe [6] when necessary.

\section{Technical parts and production of evidence}

The regimental architecture of The Audit Courts sees the process as the document formed by the successive parts to reify individual or collective decisions. Although it is not a single model, it has legal nature, nevertheless, made up of texts that present themselves as the manifest opinion of accounting specialists, business, economics, law, engineering, without running out here, based on audit findings, which are based on evidence, therefore, fully documented, allowing pinpoint the infringement upon regulatory or legal criterion to someone's responsibility. This is not a predictive report Cecchini, Aytuğ, Koehler, Pathak [7], but dives fully and irrefutably into the matter, using red flags and other risk assessment tools in the achieved complexity by managing instances of fraud and setting specific plans and self-determiners Eining, et al. [8].

In order to do not confuse the levels of the parts, its objectives and results, still preliminary, this study recognized the need to post an item separately on the conceptual and legal essence, without being a glossary, but with a similar purpose. The reason is simple, lay people might think that any term can overlap each other, mistaking their purpose, even worse, their values, not being one better or bigger than the other, unless it can effectively bring in its contents, beyond what are legal aspects of engineering. As these cases are confined to a specific place, it is necessary to understand the Brazilian law to conceptualize and circumscribe the matter, nothing that cannot be equivalent in each country. In this sense, the Council of Engineers defines the term "Inspection as a statement of fact by detailed examination and detailed description of the elements that constitute it, without the question of the causes that motivated it" CONFEA 1990. It also defines "Rating as the activity that involves the technical determination of quantitative or monetary value of a good, of a right or of an enterprise." Similarly, "Skill is defined as the activity that involves the determination of the causes that motivated certain event or assertion of rights" and "Arbitration as the activity that involves decision making or position among technically controversial alternative or that are derived from subjective aspects "CONFEA. Surveyor, Appraiser, Expert and Referee respectively are the professionals who perform the services described above. 
Therefore, it will be through the Report, in other words, the document formalized in the form of a "piece", that the engineering professional qualified in their specialties may exercise their profession in items related to movable and immovable property, its component parts, machinery and industrial plants, works and services of public utility, natural resources and property rights that, in any way, for their existence or use, are functions of these professions, will validate any of the activities described above. Violations of the normative import in criminal and administrative responsibility for the illegal exercise of the profession BRAZIL skill required to perform such procedures set out above CONFEA by Technical Responsibility Annotation, ART, for its full validity BRAZIL.

On the other hand, "Audit is an independent and objective examination of a situation or condition, in comparison with a criteria or a established pattern, in order to give an opinion or comment about it to a predetermined recipient" TCU [9] pg. 4. The "Audit Report is the part that exposes its results for proper communication," however, the legal effects start to be triggered in the regimental form of the Court of Accounts by the technical instruction TCEES [10], precisely the Initial Technical Instruction, ITI, the procedural core opening up to the contradictory TCEES [11] . It does not exhausts here the list of instruments available to the Court of Accounts for the exercise of their functions, but this line of surveillance as specified in the audit, this is the regimental way, and the External Auditor, latest name for the position that involves the individual in the technical function in what it serves.

Nonetheless, the materiality does not need to reach the whole, the definitive, moreover, is often inconclusive and inferential
Patterson \& Wright [12]. Instead, it can and should use the amount recommended in the standard that refers to the control of nature that is subject to supervision in the act of receiving the works and contract engineering services. Incidentally, this is the role of the supervising agent and internal control. In this view, the action of the technical area can with just a sample test failure characterize the potential violation of all or part of the contracted object, convention that is about to change to a minimum sample plan to be treated as a fault indication step short of investigating fraud, but it helps in triangulation of evidence Trotman \& Wright [13]. For now, and at this point said almost in popular saying in the jargon of auditors who will serve in this consignment in future defence face according to the relentless legal aphorism, plead and prove not equivalent to not claim" post Barros [14] pg. 156, simplified expression of the mandatory provision of who is authorizing expenditure accounts:

"In the Courts of Accounts proof main purpose demonstrate regular use of public resources, in other words convince the watchdog that the funds were used in accordance with the legal provisions and in line with the purpose of the respective government program. Bandeira [15] pg. 18.

The reversal of the burden of proof is not given, however, to the issues linked to the fraud leading to investigation of processes that distinguishes this very point of the audit Vona [16] he auditor need sin this investigative role to highlight facts that lead to such size, failing to cancel all initial or conclusive accusatory statement. In this ways, the criteria for allocating the accused change the administrative level, weighing the compensation and fines for the civil and criminal, alleged professional curtailment and even seclusion from society.

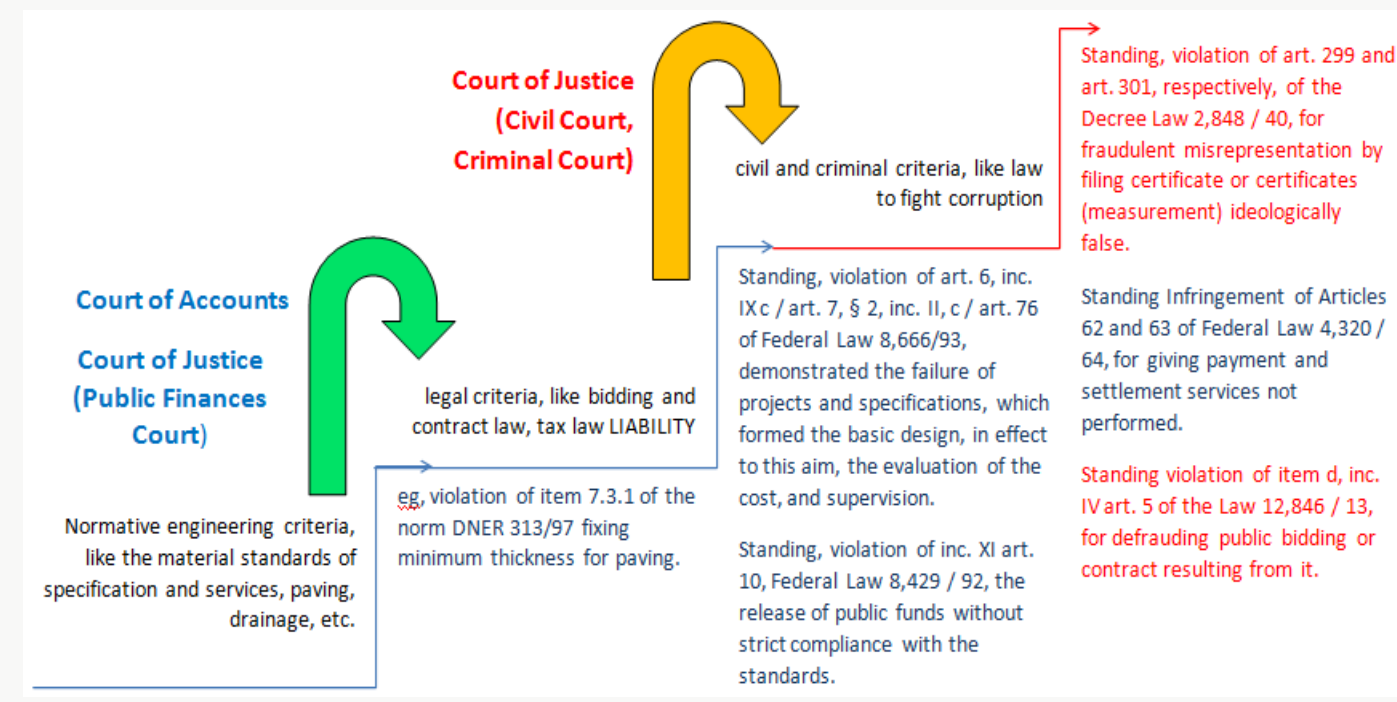

Figure 1: Criteria for typifying according to the steps that leads to fraud.

\section{Criteria for determination of irregularities}

Irregularities are attributes that can infer something contrary to the usual rules, but with no doubt in the legal criterion. The audit should point the accusatory offense that the responsible agent will oppose in his defence. It may have a purely formal nature, such as the absence of contractual clause that determines the adjustment rate, but it can also indicate the reimbursement of what is improper. In any case, it subjects to the responsibility to claim punitive penalties when irregularities rebel of the infringed legal criteria delimited in proportion to their encumbrances through dosimeter that the Court 
evaluates under the regimental precepts. No longer being capable of refuting, it will have to be signed by an individual judged by the vote of the rapporteur led to the collegiate based on expert opinion or other supervening issues. This, however, is a planned package law written in the first and second levels of (Figure 1), when using the fraudulent nature, which includes "jumping" the Court, with no claim to show hierarchy of the criteria and legal spheres, they are autonomous, but rather to observe the severity agent incurs the steps towards subsistence of fraud.

Despite jurisprudential discussions or adverse thinking to what here is taken as the work premises, weighing not enter attributes that take the object of focus to be discussed in this logic, in contractual terms of engineering works, for now affection to bidding procedures are common irregularities in a first field condemn the competitive environment, putting away from competition, but purposefully directing the object preferred. In another field, deprive the object of their minimum values with effect in increasing costs measured in the face of its execution, but in the transformation of implementation and quality of the work deadlines. The criteria are:

a) Lack of basic design (art. 7, $\S \S 2$ art. 9 of Federal Law 8,666 / 93).

b) Insufficient designs and specifications, which formed the basic design, in effect to this aim, evaluating the cost of the work and supervision (art. 6, inc. IX, and art. 7, § 2, inc.I, c / art. 76 Federal Law 8,666 / 93).

c). Disagreement object contracted with its basic design with effect on the breach of the bidding mode required (art. 7, § 4, c / c art. 23, $§ 5$ of the Federal Law 8,666 / 93).

d). Budget failure that composed the basic design, in effect to no understanding of the work involved, making it impossible to detailed assessment of the cost of the work (art. 7, § 2, inc. II, c / c art. 76 of the Federal Law 8.666 / 93).

e) Disagreement quantitative with the detailed budget in effect to be unfounded services properly assessed (art. 6, inc. IX, item "f" c / c art. 7, § 4 of Federal Law 8,666 / 93).

At least in Brazil, read: basic design as being fundamental; one capable enough to provide the scope, exhaling costs according to a executive solution, including the work specification that requires resources in a given time to an approved quality rules. That had been described in the legislation of the Federal Council of Engineering, latest updated CONFEA. It has arms in the public works in the bidding and contract Law (BRAZIL, 1993); and also in the field of audit, particularly treated in the regulatory instructions of the Brazilian Institute of Audit of Public Works during the scope and their guarantees (IBRAOP, 2006, 2009, 2011, 2016), but also in the formation of the work price IBRAOP as well as the detection of overcharging and overpricing IBRAOP. Not enough, based on the subsequent act of the acquisition management also would include: f) Noncompliance with the inclusion of the work enforcement regime in the invitation of tender (art. 40, caput, of Federal Law 8,666 / 93).

g) Irregular dispensing emergency title bid (art. 2 of Federal Law 8,666 / 93).

h) Fractionation of the bid to breach the bidding modality required (art. 23, § 5 of the Federal Law 8,666 / 93).

These attributes influence the hiring and embarrassed contract execution irregularity that disrupts the public entity in continuing asymmetry, persevering in wrongdoing. Rarely need to change the object's scope, with effect on quality, time and costs, but others, indeed a well-rehearsed vision in routine typifying these two moments of the contract, that is, before and after the bidding perspective of audit findings in contracts Zorzal [17]. Changes the nature of the criteria:

i) Illegal change of contract (art. 65, inc. I, items "a" and "b" of Federal Law 8,666 / 93).

j) Unjustified delay of the period of work (art. 8, § single of Federal Law 8,666 / 93).

k) Partial outsourcing of services without prior authorization (7th clause of the contract $x$ / $x$ art. 66 of the Federal Law 8,666 / 93).

l) Advance payment (art. 65, inc. II, "c", of Federal Law 8,666 / 93).

m) Unlawful extension of the contract term (art. 24, inc. IV, of Federal Law 8,666 / 93).

Until then, it is apparent the guilt latosensu, given the assumption that these are mismanagement, where mistakes are made under the negligence of broad terms, Hansen, Zenobia [18] recklessness or malpractice. Going back to the regimental order, the effort is abbreviated in a process that makes the calculation of damage to the treasury as the main performance. Nevertheless, in the context of fraud, one must also consider its voluntary intention to run to act, practice act or omit to achieve his own or another's benefit, premeditated or driven. Note the next criteria preliminarily taken of the case, which will be shown below:

n) Technical reports produced by the inspection not up to the services performed (art. 62 c/c art. 63 of the Federal Law 4,320 / 64, and art. 67, § 1, c / c art. 76 of the Federal Law 8,666 /93).

o) Ideological falsehood by the certificate presentation (measurement) and ideologically false certificate (Article 299 and Article 301 respectively of the Decree Law 2,848 / 40 Criminal Code).

Sensitive perspective to look at the conduct of the agentHamilton [19] sees that these criteria exceeded the border mismanagement, 
overshadowing the mere carelessness. If isolated, there would be perverting the others, not for the context of the events, which greatly burdens the treatment of fraud. Therefore, it would be the first criteria linked to the latter, a sort of ongoing infection, or at least serving as red flags. Paying attention to the conduit practiced, which is highly personal, separating from each other, among other reasons in order to enable criminality of the individual by what practice or ceases to practice, legal premise of not passing the orbit of those who practice the repressible conduct Wilks \& Zimbelman [20].

It is reasonable to assume that the criterion level goes up a level, despite being triggered by other public entity in the constitutional order of each country, in Brazil, the Public Ministry, for their enforcement agencies signed in exercise of its powers, to promote public civil action by an act of administrative misconduct and other frameworks in civil and criminal laws (BRAZIL, 1940, 1964, 1992, 2000, 2013), precautionary removal of election of public and private agents, the personal property, the breach of bank and tax secrecy in order to expand the investigation, compensation, prison, among others, this time in the face of the individual who now responsible, also encouraged by leniency agreements and the institute's award-winning collaboration tools that are not part of the administrative level.

\section{Agents' accountability}

A meaning of fraud that is found is: "the action or behaviour that, being dishonest and cunning, it is intended to mislead or deceive someone, in order to do not fulfil certain obligation or duty. "In a given context from the" action to fake anything (products, documents, brands, etc.)" Santos Neves, Cabral [21]. Within a different cultural context, values and beliefs that the individual brings Pedneault [22] would not it be a reason to qualify, but within this present context. Therefore, the maturity of its terms is seen set in deceit patronage, "one person's way of acting fraudulent over another ", especially when it takes its legal attribute, "deliberate violation of the law, per share or omission, fully aware of the crime that is committing Santos [20].

Straight reading of these terms, regardless of any law that may be established case law, tacit or explicit connection can establish perfect symmetry between any of the mentioned legal criteria unconditionally and immediately, unless by the context in which it develops. The greater weight falls and then set the intention. It is not a mere analysis that sticks to the "detailed examination of each part that makes up a whole, trying to understand everything that characterizes it", typical audit activity when searching for the standard expected, but assessment, "act of evaluating its effect" Santos [20]. Note that so far it has a specific point that supplants the cause-effect relationship, according to causation, with the characterization of the unlawful act upon conduct by the responsible individual. The mistake that can be invoked in defence Parry, Grant, Barker [23] is at the mercy of this mechanized apparatus as a treatment for fraud.
Therefore, two stages were distinguished, a first running through the world of facts, substantiating the lack of understanding of regulations on what is derived in adjectives, unfolded state of qualitative interpretation of its effect, with rules also well defined. Once observed the scope of jurisdiction, one can enter the characteristics of wrongdoing, this in turn, made on the basis of analysis of the nature of the administrative or financial offense, followed by analysis of the damage quantification criteria, and the analysis of the individualization conduct Olive [24].

The second one makes assumptions for assessing the allocation of responsibilities, what goes through the agents' conduct, guilt and expected caution, being able to follow the exclusive of illegal activity, the exclusive sanctions, particularly the absence of good faith, absence of potential knowledge or awareness, and unenforceability of adverse conduct Olive [25]. It unlocks the moment with the assessment of the causes that might impede the application of the penalty, making robust and deep understanding of the business and customer industry audited Peecher, Schwartz, Solomon [26] not in the face of primary risk, but assertive about their mismanagement. Therefore, there is thus ritual that couples to the first still unusual in audits.

\section{Research Methodology}

The scientific contribution will be the result of the observation of three specific cases in the form of empirical research on subdued fraud audit hours as necessary for its remediation. The approach to the problem is through qualitative bias, based on the criticism of the reality experienced by one of the authors in everyday work, despite the adherence to legal scales to chant the change of consolidated cool paradigm in state of the art on the normative engineering. Converging to multiple sources of evidence, come to benefit from its theoretical propositions to guide the collection and analysis of data Yin [27] within a contemporary environment without requiring control of behavioural events as they took the chance relevant situation in this research method proposed as a case study. The last cited methodological work will conduct this research axis.

\section{Research questions}

At that meeting, the gradation observed in audit evidence did raise legal engineering aspects in continued ascending making ascertain the discussion to strengthen the management of fraud, objective of the work in time to show blatant that stimulate the understanding of the subject in broad terms, accounting the first research question "how should engineering audits act in the production of evidence in the context of fraud?" that said, it goes to the second research question, "why should the audit engineering embrace procedural ritualistic in gradation criteria and accountability for the treatment of fraud? "

\section{Research propositions}

Who defrauds lives with the certainty that it will not be discovered, being willing to cover up their actions to not make 
the act. On the other hand, the auditor who is in the procedural front has enough reasons to undertake, to employ differentiated investigative actions compatible with the difficulties of coping to come, which is the research proposition supported in permanent difficulty to subsidize compensation action in courts of auditors and other actions in civil and criminal justice immediately related.

\section{The unit of analysis}

By exploring a concrete case transcribed in the form of an inspection process that ran through a municipal administrative management carried out in a Brazilian city, in particular to say, another limiting research, it would be so crucial to impound fraudulent process at the time lived. Ordinary audit did note about fifty-three contracts in twenty works and engineering services, representative sample that exceeded $45 \%$ of expenditure in the annual budget as rigged, among more than $80 \%$ considered in prioritizing an $\mathrm{ABC}$ curve.

Now arise in the form of a "problem-situation" after analytical outcome of the technical area, which showed various types of configured schemes for misuse of public money, three of which were brought to light in this text because they are more available to management reliability in legally symmetrical places in other countries, requiring over-specialized effort to counter solution before analysis of the complexity of what is broken in financial importance to be discussed in litigation, therefore, no more administrative. Moreover, the cultural circumstances defined the dimensions of the ethical and moral diving necessary to combat the corruption case of impunity, which survives in delays.

\section{The logic that links the data to the propositions}

First it is important to say that the observation was systematized and structured pedagogically in four times on a management cycle in the following order:

a) Historical review according to instruction cycles in a Court of Auditors;

b) Observation and modelling of schemes based on the contractual redemption of works and arbitration between accusatory fruit of evidence (audit findings), surpassed the defence with effect to the recognition of fraud;

c) Observing the conduits promoting accountability. In order to demonstrate the desired consistency objective of this study, it was proposed three cases in "problem- situations", say less sensitive replication logic Yin [27]; Scholz, Tietje [28] showing the path taken to treat fraud.

This part that consists in the production of overwhelming evidence of its existence, superimposed calculations that place the order of magnitude of the diverted resources, and answer the first question. Otherwise, it invokes individualized compensation, being nothing more than situational descriptive result of their conduct subject of the frame by increasingly strict criteria, in fact, answer the second research question, because it is a sine qua non for support procedural ritualistic before full of evidence based in attitudes sometimes acclimated, but still empty of the true intention, motivation.

\section{Criteria for interpreting the findings}

At this meeting, different views will be placed as assumptions that represent the expansion of the literary scene that reads fraud, according to what can be given treatment, alleged finally to a model, purpose of the research, in time to show blatant that stimulate the understanding of the subject in broad terms. It is used concomitantly of office of the procedural document research of the authors, although limiting the space-time experienced in the early safeguarded by judicial secrecy was imposed still can say extemporaneous. Despite the diversity of topics, and varied discourse on engineering issues, there is division in the dealings of the legal aspects that matter criminalization, recurring results of the discussions in spite of the stubborn presence of shakers to stop any form of pre-judging, or pre-conceptualize the thesis before the evidence, novelty that explores this methodological bias. Not only in the course of the results sought to chant the dispute between findings, to place firmly the principle framework of people in the fraud, one criterion suggested by whom defend a case study in view of the quantitative statistical insignificance. It can be said that their structures were observed in many other cases with similar symmetry that allowed affirming self-sufficiency of procedural rigor to a greater extent than the three that were presented.

More than that, it was not the change in the tonic of this work to another approach, which would escape to this subject, there is evidence to systematize the rite in the form of model to qualitatively infer the level of fraud to which they subject an entire population when administered by organized crime, and from there, produce future quantitative work, nevertheless, able to understand the structure of the phenomenon in order to develop hypotheses, models and today's theories Scholz, Tietje [28].

\section{Case Study}

The three "problems-situations" arise in municipal administrative management that reached populations just over a hundred thousand people in the past decade. It is an action of ordinary inspection, provided by regulation in external control activity, but without regimental outcome, partly atypical decision account that unfolded in diligence, in fact the biggest procedural work lasting four years in troubled litigation environment, which the end leveraged the criticality level of the legal criteria, expanded the list of responsible, allowing for return would reach three times the initial value. After defence managers, tax and business, in the face of exhaustive arbitration work another two years to prepare the concluding piece of engineering on the initial terms, there has been forwarding the administrative level, this unfolded height of the civil and criminal sphere of justice. 
Because of the size, scope, complexity and relevance, it is that job formatted pedagogically in two instructive cycles that began to reveal the understanding of two different periods, both brought to technical opinion rebuilding the elusive administrative modus operandi in time, brought to term in fraudulent basis, to recover their legal status to be taken finally on trial. At the end, rehearses the perspective of various schemes set, blaming its characters typified conduct. The framed case study was sufficiently put to question the treatment of fraud, it is taking model on which meets three problem-situations which now lack the historical rescue to do next contractual observation, technical engineering benchmarking.

\section{Procedural historical rescue Legal and produced evi-} dence

Exploring the legal environment in its procedural course that can reach 20 years or more until your final judgment, to observe and learn about aspects of fraud in their intimacy, expression that forms in (Figure 2), notice the flowchart setting chronology, the drawing actually happened, in the midst of the shadow of legal process would be the procedural core, surrounded by suburbs where the engineering parts that support it, contributing both to mature future decision of the plenary.

The nucleated position is legal, are pieces that legally instruct the process, in this case primary purpose of exercising the adversarial role of the state, e.g., Initial Technical Instruction, ITI, essential imputation of the conduct of the person responsible to the infringed criterion on the basis of findings, working papers that are attached to the audit reports, e.g. Legal Audit Report, RAJ, Engineering Audit Report, SAR, diligence, DIL, in outline. After the contradictory exercise the right of broad Defence, DEF, the technical area must opine definitively in engineering piece, Conclusive Technical Instruction, ITC, following the Legal opinion, PJC, the public prosecutor, to be brought to the decision plenary. The occasion plot of spite, DP2 path would be resumed in DPD6 in the same (Figure 2).

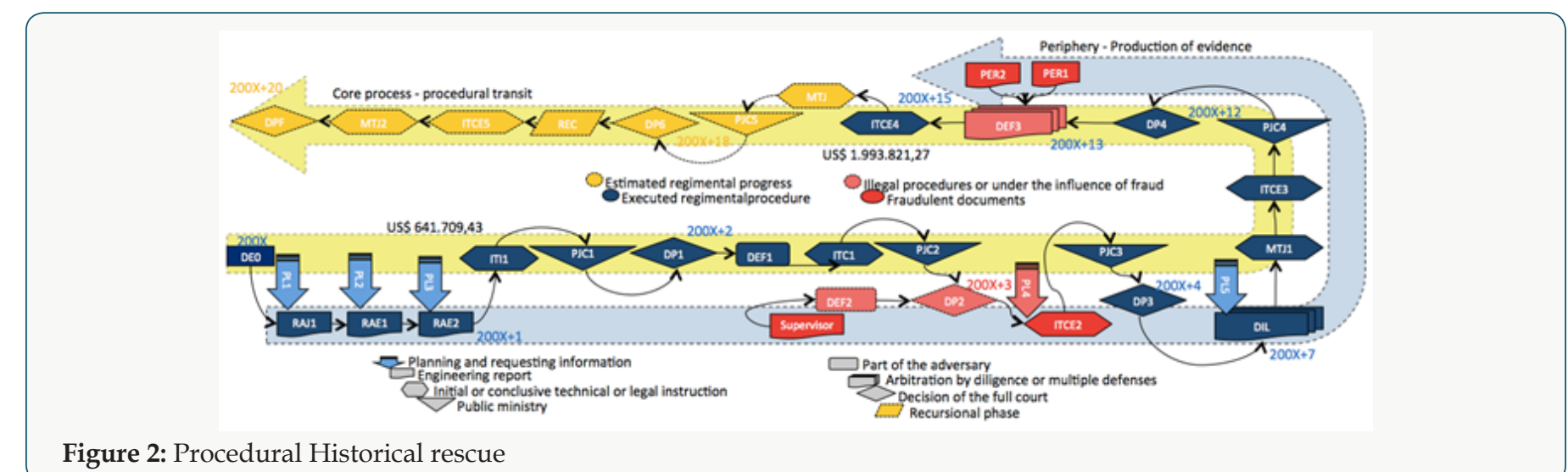

Figure 2: Procedural Historical rescue

Meanwhile, at the mercy of the defence interference, watch up to their relentless production appellate strategies of new evidence, e.g. skills, PER, would cause huge shuffle, but the insistent repetition of terms within the same parts, e.g. DEF, unaware of any new fact, mere fact that denies the conclusion of the work, procrastinating sense the broad terms under the legal protection than would be the exercise of legal defence and the adversarial.

By the principle of regimental loyalty, despite the normal work regime, observing the procedural zeal, there would be spending three years without a decision. Would not, moreover, any space to cross the procedural course with strange parts, although it has been observed in this case your presence with intriguing tolerance of the judge collegiate, distorting large-scale chronology, with serious damage to his recovery, in whose energy expended would be qualified as rework, deriving a course that exceeds fifteen years determined to fight corruption, recognized in due diligence work, the larger scale.

Overcome the issue, this diagram does not refrain from seeing who came out of a plateau in the vicinity of U\$ 650,000, the first education cycle to another almost $U \$ 2,000,000$, after conclusions of the technical area of engineering, more than three times the original value of the audit, outside the fines that could follow. Weighing the costs for recovery of the compensation process, with strong inclination to end punitive prescribility of all agents, the result of procedural inaction taken by the necessary recovery, would then be significant $\mathrm{U} \$ 550,000$, close to $27 \%$ of elevation to return to the treasury, inquiring its usefulness through the absence of criminality, which goes beyond the terms of the play, a time when judges embraced in scandalous legacy, all unscathed from their crimes.

\section{Contractual observation and modelling of schemes}

Peripheral pieces of engineering that supported the concluding arbitration to be brought to trial, although preceded by the merged legal opinion of the prosecution, have taken on a set of twenty works in separate contracts, storing devious schemes that transgressed the established power of one side of another funding being funded in perpetual status quo. Deepening reading about hiring itself and its respective contract execution could be bringing three of these schemes that competed at the core of the fraud, and as a result, infer the treatment of fraud according to the strategic, tactical and operational, see (Table 1). 
Table 1: Treatment of the second approach fraud.

Strategic level for the treatment of fraud: The clash demanded elaboration of issues, so investigative character, deciding the forward and backward in time on the same object through the superimposed observation of contracts, and determining use specialized human resources, encouraging the collection of field data, including those excavated. Alie call to capital institutions in the accusatory process of fraud in the case the prosecutor, including that of delaying nature, expanding the visible horizon of events.

Tactical level: The use of own laboratories for materials testing, and topographic measurements of the field, or his hiring that can refine the quality of information that is available for the production of evidence, be careful if taking with calibration equipment, certification of contracted institutions, with appropriate monitoring in the field, laboratory and office.

Operating level: Employing refined engineering knowledge with effect to reverberate care in producing evidence, subject to the accuracy of document analysis, consistency in the classification of the criteria the impact of the findings from the minimum basics of engineering standards, assessing trends for further assessment that would allow value judgments on the legal criteria on suspicion indeed accountability under the pipes. Write the audit report with objectivity, clarity, conciseness, opportunity (this tends to succumb in the legal aspects of punitive prescription), relevance, materiality and usefulness(IRB 2010).

Problem situation: Duplicity or Triplicity of Payments, under a pseudo paving scope and urban drainage on a large scale in the city in full development, to justify their investments under the umbrella of grace, conceived a series of fractional bids in pieces such that deprived the legal limits allowing favour local companies in affecting distribution cartelised if not directed, overlapping competition with effect to successive agreements on these works packages. This practice is recurrent among those who are active in public, but also private works, often through contractual bonuses in veiled agreements cooperatives, trade unions, and business associations.

This facade disguising the competition, at first makes the price increase by the decline of the discounts offered, deployed in the contract execution, which in this case is covered by a street scope, avenues, partially or entirely executed in old contracts, some of them in previous administrations, under the pretext of achieving only receipt for something that is already done. Audits often pass others to the supervisory process accommodated in the fiscal year when a lot in running a government in the midst of closing the figures to be taken to the statements on the budget execution, compliance with their legal limits, etc.

Upon receiving the requested documentation it is not realized that there is overlap of the object, paid in duplicity, triplicity, as is the case, notably observed on the vision of a magnifying glass that covers this subject in at least two years behind the calendar note and forward as much as possible, see (Figure 3). Note that all the stain becomes a patchy quilt of six other agreements, including making use of local labour in campaign for regime humble people living there except inmates in feather compensation scheme, receiving the city complementary resources of manpower, supplies, machinery and equipment, i.e. fully implemented object with low cost and already paid.

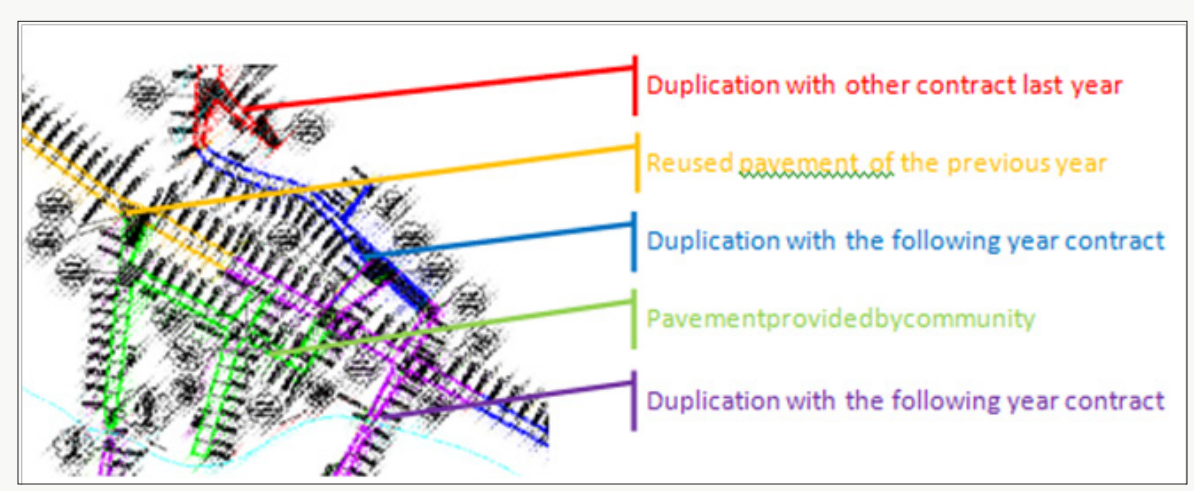

Figure 3: Survey of paved areas in hexagonal block and drainage gutter curb in one of the neighborhoods in duplication with a contract.

This case is in line with the observation of scope in the perspective of time, as a remedy for the treatment of fraud. This modus operandi interests in two crucial points: first that there would be another contract appearing in overlay, No accounting entry even less inputs in existing personal accounts. In this gap, another contract, false, would be in a position free of suspicion. Second, that the contracts in force are explored in size fragments loose in many different neighbourhoods around the city in a provision alleged to pavement completion, mere expansion, in which the overlap would be unquestionable, and demotivating for the average man to check. However, these two situations are as premises, coincidences that lead to the projection of fraud experienced auditor's observation.
Eschewing a geo referenced data management system would mismanagement to go unpunished Zorzal [29] tools that were not customary at the time.

In vivid colours in (Figure 3) note that diligence come in successive field measurements every ten meters, small lines perpendicular to the road layout, attaching surveying and calculation memory to compose the area subject to measurement in each of the separate previous agreements and further to that analyzed. This is the point that emphasizes the treatment of fraud, separate contracts of objects that have been paid in duplicate contemplated in the invitation notices distinct in simple sketches 
language, process manuscripts drawings means the defence of the managers was achieved pay attention to contradictions between plants, by the way another flashy point in the treatment of fraud, documents overlap in saying you do not hold up over the plot. Despite this, it is very common to invoke defence document similar, if not identical, which makes analysis as if it were different, accumulating in distant overlapping pages in the process, the more than ten thousand pages. This view tends to confuse the inattentive, bored the persevering, interspacing deliverables and generating internal and external costs, while the social in a larger scale.

On the one hand, there is the effort to produce evidence in the accusatory act, on the other there are insistent procrastinating desirable to later invoke punitive prescription. In this case, the fact that there is a key point that distorted the procedural course of his regimental history, resume (Figure 2) to find in it a second conclusive piece of engineering, IEC2 produced in a means to an undesirable documentary superficiality, the result of less month working in the same technical area in the service of fraud, regardless of other sector, should be seen as a result of the dark current employment tribunal, reticent era that ended in removal of judges days later, suggesting influence of cited in unthinkable regions of State.

Not enough, the debate acquiesces when inserted expert parts, a contingency used by defences managers and entrepreneurs to the same indirect purpose of procrastination. In this case, audits use the diligent's documentary remittances suitable for babbled useless exchange of numbers from one to another contract, without evidentiary innovation, only denying the form placed by accusatory, as the piece predecessor, a presentation committed to dependence and loyalty to a customer Moyes, Anandarajan [30]. Despite the confusion, the results remained, passing unscathed to criticism of the contradictory. This gave rise, instead, to call on the use of experts and auditors in misrepresentation, in effect now of representing the notary organs professional supervision, and even justice through action improper conduct of the prosecution to respond civilly and criminally, effect treatment of fraud.

Problem situation: Playing Spreadsheets and Compensation for Chemistry with Effect to Overpricing. On the same road network, now in engineering solutions inherent in the use of asphalt pavement, preceded by earthworks, within the obscurity of such services buried environment, so little subject to thorough examination of the layers already implemented, it can be seen hiring exaggerated in the specification means the superstructure and infrastructure. In fact, both the frequency of expected traffic as their charges would subject accommodate a flooring solution too much for what is conjured run. In fact, the project was criticized by managers in their own defence, in a way embittering a previous confession of initial contractual contours, which confined to undertake further research in the face of diligence. It was at this point that hired foreign materials testing laboratory to the territory of the court, accompanied by the technical area, public prosecutors and the tax works and executing companies, some of them wealthy in his own image Power [31] citing its long years of unblemished market his name, conceit that does not fit. Nevertheless, the survey samples, there was window prepared to conceal the services performed as if they were made on a large scale, see (Figure 4), against all that found in the tests so far submitted by the same defence in times of work, one of them disfigured grain size of the contracted standards, and staggered the testimony of people who followed the works on the door of their homes. These were the major red flags found: The case in question is typical: as the source of gravel is known in the initial project, with enlarged distance transport, the contractor believes in its logical seek the one that is closest; then choose in the list of options trading, a mixture of cheaper stone in the case, complemented with local soil replaced purposely poorly sized project.

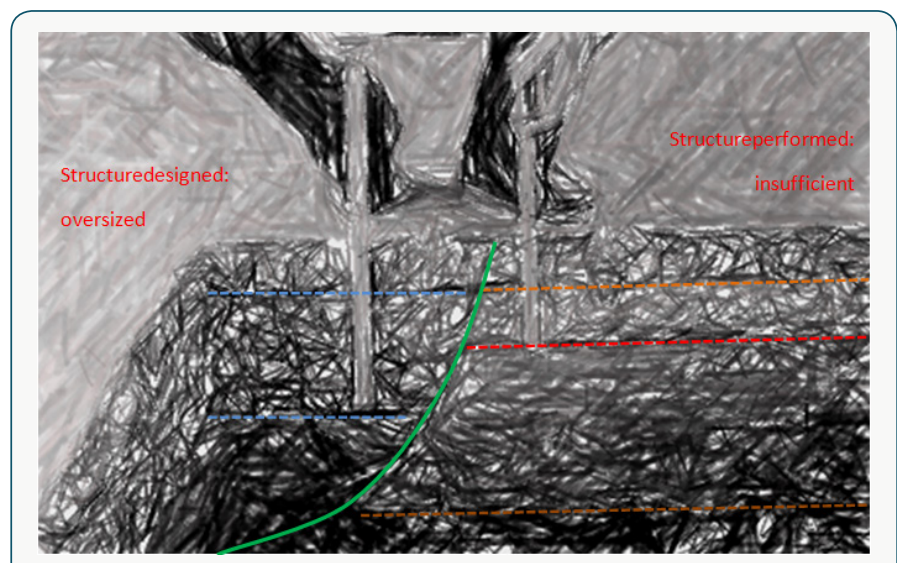

Figure 4: Prepared Area Marking Figured That Dissimulation.

Therefore, results from laboratory tests indicated distinct deposits from those indicated on journeys that reached $75 \mathrm{~km}$ for payment of transportation distances from the quarries, found in the core of (Figure 4), illustrating the tamper inputs to what would be crushed at the base and mixtures in the other layers in addition to the volumes of materials inattentive to the specified order of magnitude of project, say also vilified for what would be the reality of local traffic. Aside from that, even the earthwork is configured high for payment, very shallow in immediate superficiality, as shown in (Figure 5). Spread this deception on the mesh of a city and see the size of embezzlement, and its common defence a support unsuitability of used laboratory, one of the largest in the country, questioning the calibration of equipment upon expert report produced by the odd training area. This case is in line with the observation of quality in the scope of perspective as a medicine for the treatment of fraud. In fact, this case could be confused with the next by replacing the price of quality for quantity, and vice versa. However, the movement that is made here is in her reduction sense, there will be seen is its expansion. 


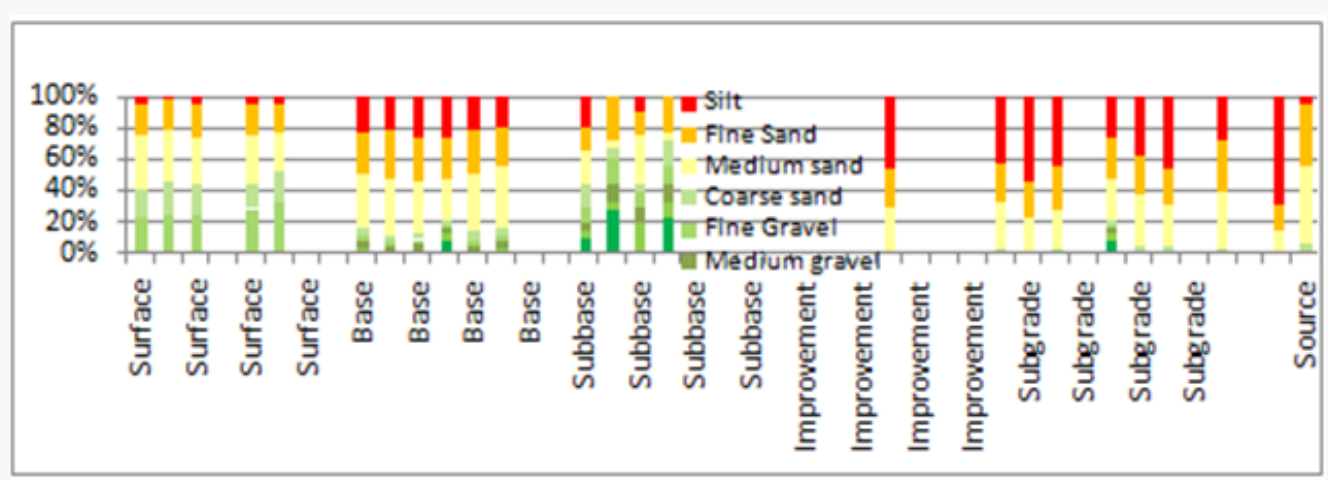

Figure 5(a): Standard grain size obtained in laboratory tests indicating presence of large local clay material.

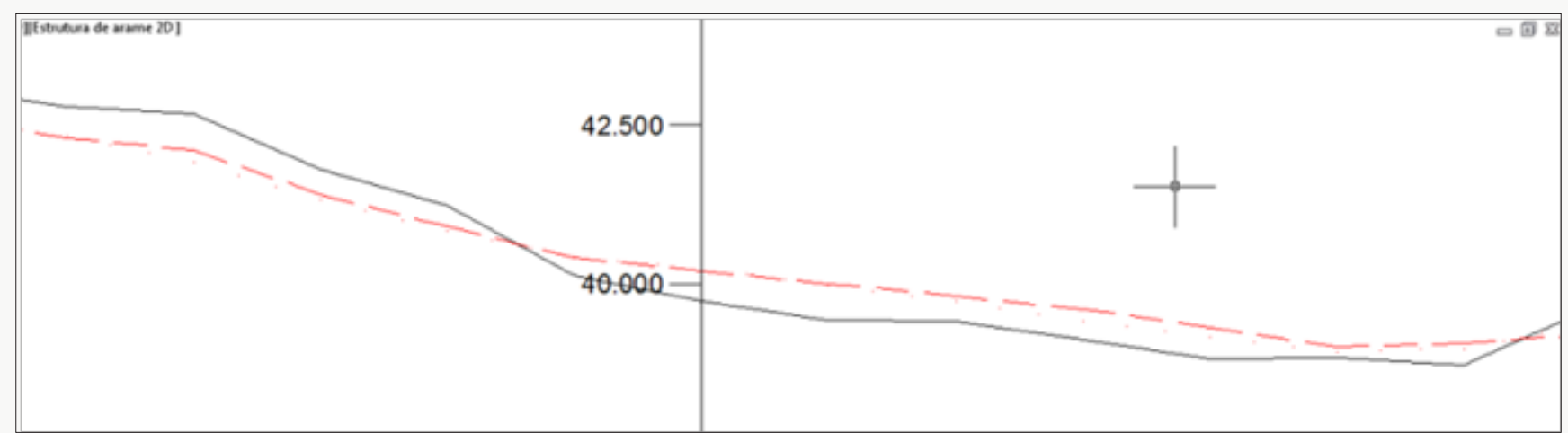

Figure 5(b): Longitudinal Profile Specified In Fills 2.5 M Long Station 160 fill $50 \mathrm{~cm}$.

Figure 5:

Problem-situation: Renegotiation and contract adjustment with effect to overpricing another contract macula was found in the transport collection contract and final waste disposal, providing a fleet more than doubled as the start date, passing the time in contract execution typified the lower your costs when compared to the rewards set at a level bigger. (Figure 6) shows unexplained features, in fact disconnected from any economic growth curve, and it vegetative. If enough, there was no contractual provision rewrites the adjustments the sector over successive four years, weighing the decision to use within all available in econometrics, one with steeper the curve, averse to inflation of the health sector.

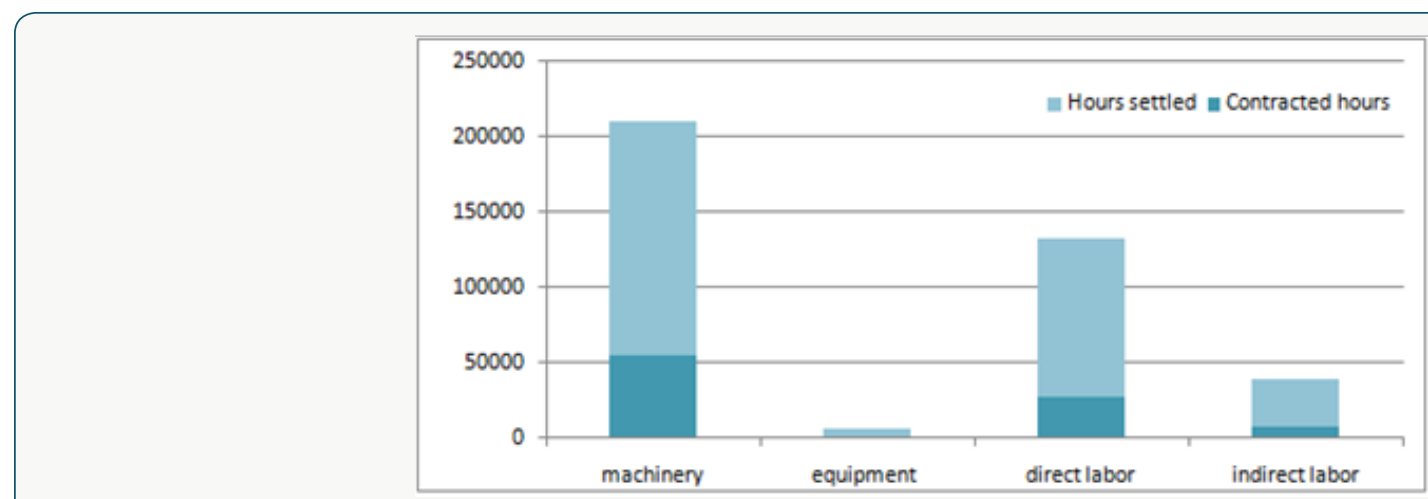

Figure 6: Number of hours contracted $x$ number of settled and paid hours (renegotiation).

Isolated fact, there would be no support fraud on what would be mere provision of oblivion, even with such offer similar notices on the market that reaches at least $40.1 \%$ of the national counties PWHC [32] nor make some readjustment, but use of projections so overwhelmed demand (Figure 7), with wildly index of reality, plus significant amounts of contractual inputs without adherence to any growth curve, apart from using hand municipal work, road sweepers of city hall itself. Despite the procedural course already be evidenced spreadsheet game clue at this point about what would be the amounts, inattentive, however the contractual items relating to renegotiation and adjustment, which reflected in the share increase of the compensation due to the second cycle, raising the level of compensation for three times. Another motion is due to recall the scope of the discussions, not be susceptible only to the critique of 
price alone, but also the lack of proof for settlement. This case is aligned with the observation scope in costs and time perspective, seen in the readjustment replanning additives and as a medicine for the treatment of fraud.

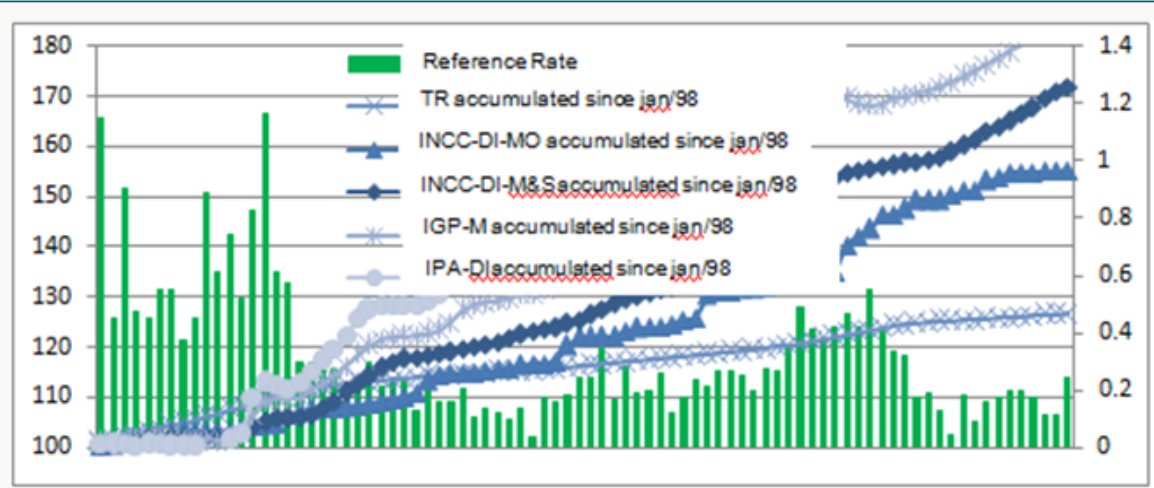

Figure 7: Comparison of these Ratios Addressed Routes for the Purpose of Adjustment Since Jan/98.

False numbers held irregular measurements involving an orbit that pass by actors in roles that contribute to the fraud scheme. Tax City Hall certifying services agreements with companies, not without the approval of municipal works secretaries, supported by the then mayor to gear swirled. However, this process needs to prove the economic and financial ties implied in the perpetuation of political power through economic power that turned the benefit of all in the scheme, which is the higher limit of operation of the courts of accounts. Break tax secrecy, financial, telephone instruments are not provided in this administrative level, but they support the impetus to other spheres act in this direction.

\section{Observation of behaviour practiced for accountability}

Overcome reading that described the fraud schemes without depleting these, it was possible to pass the accountability work, and however, it is subject to another treaty, summarized here to make up the fraud treatment model, last methodological prerogative in line with the goals. The number of agents exceeds fifteen between public and private, even legal entities are personified to some of their representatives, acting on behalf of it. The main coordinator of this criminal organization was understood in the person of the mayor, the beneficiary of political power, which engendered its central position characterized in attention to this ideal, so it developed positional planning secretaries in your folders, unfolding rhetoric mandatory from the preparation projects through the bidding committee to the inspection of contracts, in fact a managementoriented model for certain participants companies of fraud, noticeable even in terms of each contract, guaranteed to economic power in a vicious circle aware of the status quo established.

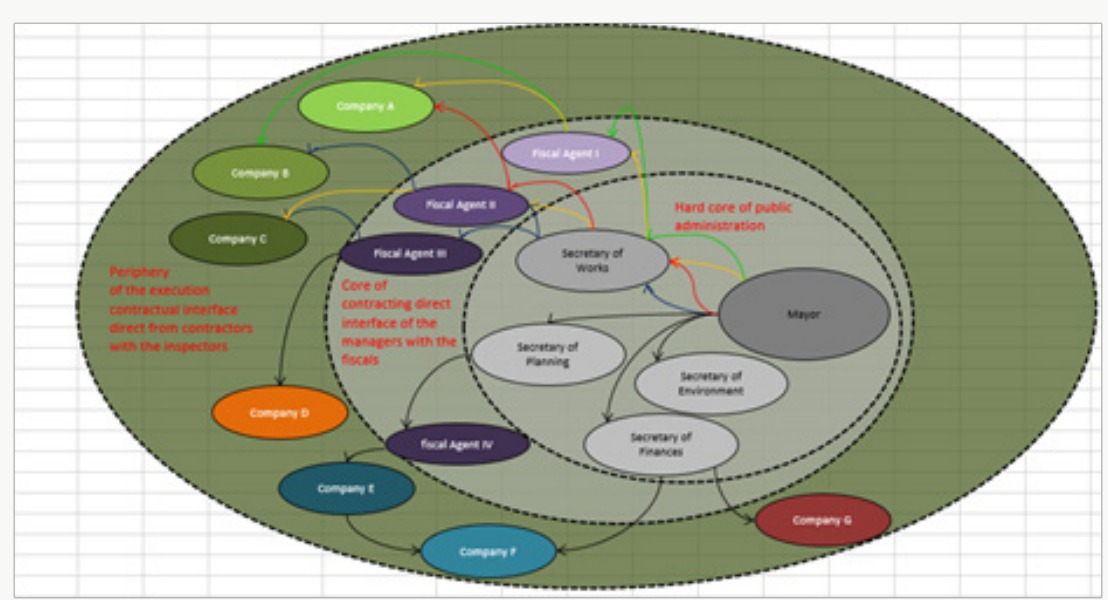

Figure 8: Neural agents according to contractual links.

The worsening picture when you look at the whole of the works, which are organized in groups of the same nature, conforming schemes, depending on the modus operandi of their work, using some strategies. Refer to (Figure 8) of the nerve that connects the other characters conveying the communication, to integrate agents each with its role in the conduct of their contractual legacy. Would the mayor combine the articulated arm with subordinates, secretaries, tax-engineers and companies in unequivocal conspiracy say with the changed graphics of this speech, if decharacterizing-altogether the possibility of mismanagement, the reverse capacity of its servers in which wedge in the path that reaches several stages to fraud. At this point it stood out duplication of objects in different contracts, but not before distributing who interested him do considering the promoted fractionation (Contracts 01, 02, 03, 04, 05, 06, 12 and 
13) without enforcement regime set (01 contracts, $02,03,04,05$, $06,15,19$ and 20); or even irregular dispenses with subterfuge in emergency situation (Contract 20), as a strategy to achieve its harmful intentions. Moreover, if the asphalt type (Contract 07, 08, 9:10). There are enough reasons to believe in a great design that turned to extrapolate too much in the quantities of materials used even specification, but settled and paid as if they were focusing on the remains that could earn them all. Premise identical participation of its so if it had insufficient projects (Contract 01, 02, 04, 05, 06, $07,08,09,16,17$ and 20). On the other hand see that alone was able to promote the embezzlement in spending without legislative authorization (Contract 11, 12, 13, 14 and 21).

Indeed to something greater, since in the face of diligence, was discovered in the area of deception prepared to denote what had been hired. Not enough, you see pitch in the management that made the particular (Contract 03, 04,11, 14 and 17), or even of payments adjustments to falsely balance contracts (Contract 02, 10, 13 and 20 ), the apex the household garbage collection contract clearly exceeded the replanning amounts and forged readjustment in the highest rate available. In means the diversity of other assessments contained in the core of (Figure 9), has not gone unscathed to any of them. This case is in line with the observation of (human) resources in the relational perspective of integration as a medicine for the treatment of fraud. It is not usual reckless management in naive and singular sense, but the antithesis of public management, here nominated anti-management, predatory and mismanagement. Public servants using public machine in collusion with businessmen who did not respond at any time in this process, lapse that will be repaired in court.

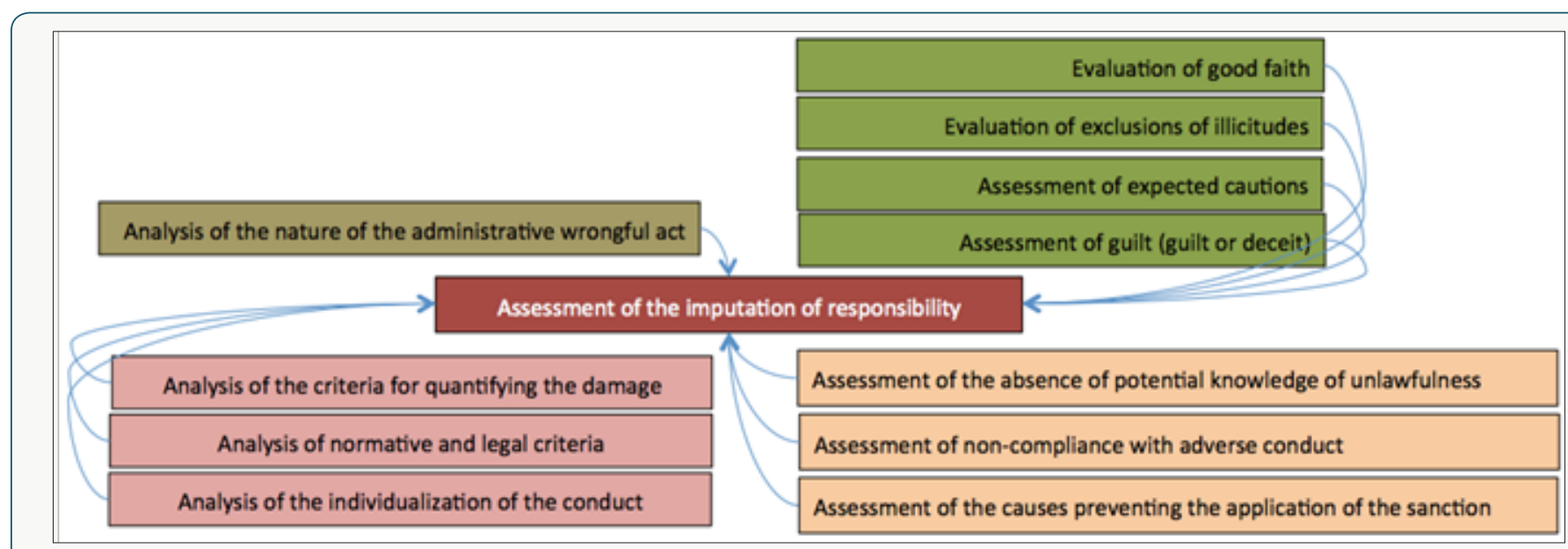

Figure 9: Evaluation of the Prospects of Responsibilities.

\section{Conclusions and Final Considerations}

Fraud Evaluation after presenting all the procedural history drawing the debate between prosecution and defence, even on the threshold of the first investigative cycle, a vain attempt to hide fraud Simon [33] bitterly in almost seven years between coming and going, we had outcome of the investigation into distinct action audit, which unveiled report and subsequent technical education. This first phase takes reading on the makeup impunity in legal defence and contradictory, placed indelibly to the postponement of purposes, involves other actors (experts and auditors, tax and managers) in unequivocal collusion accusation promoted procedural delays in apparent impunity.

More than regulate the audit quality in their confidence and legitimacy Holm, Zaman [34] it also re establishes the regulatory framework in secular political semantics that may have, on whose accuracy is sine qua non to subsidize production of evidence of its existence that will serve the ritualistic process. However, out of the normative sphere to prospect legal criteria in a given context, it allowed the triangulation of information; it is possible to characterize the voluntary conduct of agents in such quantities that reached fraud as a result of the evaluation. Aside from the purely descriptive character of the case presented, the scientific contribution is left in propositional triggering gradation legal criteria before the individualization of conduct a practice that burdens the technical work, but raises the procedural level for the subsequent trial, being consistent as fraud treatment model. The modelling afforded the transfiguration of regulatory compliance Legal administrative, civil and criminal was explored in the works and engineering services in the fraud environment brought to term into the public accounting.

On the other hand, in this environment of works and engineering services is not common on with the work of evaluation of behaviour, according to the dosimeter of responsibility of each agent in depth was made, taking its effects in aggravating or mitigating, or even discriminate who truly contributed to the wrongdoing. This is a field of research that is open to new connections between these two environments that demands merging the legal aspects of engineering, still very connected to the world of accounting and finance, especially the impact of audits on investors McKee [35] and their legal disputes unfolding, which otherwise is capable of producing evidence to support the accusatorial at high levels to combat white-collar crime. 
Would that be enough? After all the time the amount was significant when considering that the majority of Brazilian municipalities, but world settle into smaller budgets than the compensation that arises from this. If you believe that is inserted in a state that does not mean two percent of Brazilians, it gained another sense, anonymity. However, if this be reflected connected across the country, after all in 2008, the existing 5,565 only 252 were with a population of a hundred thousand and one million inhabitants, the latter resonating fourteen of them, you can imagine the rest precariousness of 5,299 municipalities with population less than hundred thousand inhabitants, nearest contingent of inferring be in similar situations. In this case, if $10 \%$ of the budget is that for fraud Ruimschotel [36] thesis that expands on the significance in this case study, this would result in a large amount of resources of a country.

In this forgettable place that anti batch management professionals have to disfigure the municipal, state and federal treasury through the agreements, pretended to get rich. In them, External Control filters are innocuous in the disparity in the cost effectiveness of the audit: and they know it. From time to time, in an action of this size, it makes someone caught. We are not here exhaust the infinite forms of possible schemes Vona [37] but to be part demonstrative conclusions on the harvest of engineering in its diverse optical normative and legal, which led to reflect the scientific community, even disfigured their characters, dates and contracts at heart to preserve the authors, to be the case yet unfinished scale people dress still wield power. As it stands, it is a fraud evaluation model, at least the legal aspects of engineering [38-54].

\section{References}

1. Jarzembski W (1989) Some legal aspects of engineering. IEEE Potentials 8(4): 30-31.

2. Loebbecke JK, Eining MM, Willingham JJ (1989) Auditors experience with material irregularities-Frequency, Nature, and Detectability. Auditing-A Journal of Practice \& Theory 9(1): 1-28.

3. Francis JR (2011) A framework for understanding and researching audit quality. Auditing: A Journal of Practice \& Theory 30(2): 125-152.

4. Gottschalk P (2015) Fraud Examiners in White-Collar Crime Investigations. CRC Press, pp. 298.

5. Blegvad K (2007) INTOSAI's New Professional Standards Framework. International Journal of Government Auditing 34(4): 11.

6. Cormier D, Lapointe P (2005) To assess and detect. CA Magazine, USA 9: 51-54.

7. Cecchini M, Aytug H, Koehler GJ, Pathak P (2010) Detecting management fraud in public companies. Management Science 56(7): 1146-1160.

8. Eining MM, Jones DR, Loebbecke JK (1997) Reliance on decision aids: An examination of auditors' assessment of management fraud. Auditing 16(2): 1.

9. TCU (2011) Curso auditoria governmental: Fundaments de auditoria governmental. Brasília: TCU.

10. Lei Complementar 621 de 8 de março de (2012) Dispõe sobre a Lei Orgânica do TCEES.
11. Resolução TC 261 de 4 de junho de (2013) Aprova o Regimento Interno does TCEES.

12. Patterson E, Wright D (2003) Evidence of fraud, audit risk and audit liability regimes. Review of Accounting Studies 8(1): 105-131.

13. Trotman KT, Wright WF (2012) Triangulation of audit evidence in fraud risk assessments. Accounting, Organizations and Society 37(1): 41-53.

14. Barros HD (2007) Relatório de auditoria diligencial. Retrieved from Vitória.

15. Bandeira MDO (2012) Ônus da prova nos processos de prestação de contas perante os tribunais de contas. Brasília.

16. Vona LW (2012) Fraud risk assessment: Building a fraud audit program. John Wiley \& Sons, pp. 224.

17. Zorzal FMB (2014) Gerência de Contratos: Propostas técnicas para licitações publican’s e privadas. PACO, São Paulo, Brazil.

18. Hansen K, Zenobia K (2011) Civil engineer's handbook of professional practice. John Wiley \& Sons, pp. 744.

19. Hamilton EL (2013) Evaluating the Intentionality of Identified Misstatements: How Perspective Can Help Auditors in Distinguishing Errors from Fraud. Auditing: A Journal of Practice and Theory.

20. Wilks TJ, Zimbelman MF (2004) Decomposition of Fraud-Risk Assessments and Auditors' Sensitivity to Fraud Cues. Contemporary Accounting Research 21(3): 719-745.

21. Santos DR, Neves FDS, Cabral LF (2016) Dicionário online de Portuguese. World Wide Web.

22. Pedneault S (2010) Fraud 101: Techniques and Strategies for Understanding Fraud. John Wiley \& Sons, pp. 234.

23. Parry C, Grant JP, Barker JC (2009) Parry and Grant encyclopaedic dictionary of international law. Oxford University Press, USA.

24. Oliveira OC (2014) Processo nos Tribunais de Contas. Treinamento interno para auditors do TCEES. Tribunal de Contas do Estado do Espírito Santo.

25. Oliveira OC (2015) Responsabilização de agentes públicos e privados perante os Tribunais de Contas. Treinamento interno para auditors do TCEES. Tribunal de Contas do Estado do Espírito Santo, Vitória.

26. Peecher ME, Schwartz R, Solomon I (2007) It's all about audit quality: Perspectives on strategic-systems auditing. Accounting, Organizations and Society 32(4): 463-485.

27. Yin RK (2013) Case study research: Design and methods. Sage publications, UK.

28. Scholz RW, Tietje O (2002) Embedded case study methods: Integrating quantitative and qualitative knowledge: Sage publications, UK.

29. Zorzal FMB (2013) Gerência de Cidades: Infrastructure com estudo de caso para a Cidade de Curitiba. São Paulo: PACO.

30. Moyes GD, Anandarajan A (2002) What Kind of CPA Detects Fraud? Internal Auditing-Boston-Warren Gorham and Lamont Incorporated 17(5): 32-41.

31. Power MK (2003) Auditing and the production of legitimacy. Accounting, Organizations and Society 28(4): 379-394.

32. PWHC (2014) Gestão da limpeza Urbana: Um investment para o future das cidades. Price water house coopers.

33. Simon CA (2012) Individual auditors' identification of relevant fraud schemes. Auditing: A Journal of Practice \& Theory 31(1): 1-16.

34. Holm C, Zaman M (2012) Regulating audit quality: Restoring trust and legitimacy. Paper presented at the Accounting Forum 36(1): 51-61. 
35. McKee TA (2010) The' cry wolf' problem in current fraud auditing standards. The CPA Journal, 80(1): 60.

36. Ruimschotel D (1994) The EC budget: Ten per cent fraud? A policy analysis approach. JCMS: Journal of Common Market Studies 32(3): 319329.

37. (1940) Código Penal 2848/40 CFR.

38. (1964) Estatui Normas Gerais de Direito Financeiro para elaboração e controle dos orçamentos e balanços da União, dos Estados, dos Municípios e do Distrito Federal.

39. (1966) Lei Federal Número 5.194/66. Dispõe quanto ao exercício por profissional de Nível Superior das atividades de Engenharia de Avaliações e Perícias de Engenharia.

40. (1992) Dispõe sobre as sanções aplicáveis aos agentes públicos nos casos de enriquecimento ilícito no exercício de mandato, cargo, emprego ou função na administração pública direta, indireta ou fundacional e dá outras providências.

41. (1993) Regulamenta e institui normas para licitações e contratos da Administração Pública e dá outras providências.

42. (2000) Estabelece Norma de finances publican's voltadas para a responsabilidade na gestão fiscal e dá outras providências.
43. (2013) Dispõe sobre a responsabilização administrative e civil de pessoas jurídicas pela prática de atos contra an administração pública, nacional ou estrangeira, e dá outras providências.

44. (1973) Dispõe sobre a Regulamentação da profissão de engenheiro.

45. (1990) Dispõe quanto ao exercício por profissional de Nível Superior das atividades de Engenharia de Avaliações e Perícias de Engenharia.

46. (1996) Dispõe sobre an arbitragem.

47. (2015) Conceitua o termo Projeto e define suas tipificações.

48. (2006) Projeto Básico.

49. (2009) Obra e Serviço de Engenharia.

50. (2011) Garantia Quinquenal de Obras Publicans.

51. (2012a) Métodos e Procedimentos para Apuração de Sobrepreço e Super faturamento em Obras Publicans.

52. (2012b) Precisão de Orçamentos de Obras Publicans.

53. (2016) Anteprojeto de engenharia.

54. IRB (2010) Normas de Auditoria Governmental - NAGs: Aplicáveis ao Controle Externo. Brasília: Tribunal de Contas da União.

\section{(c) $(9$ \\ This work is licensed under Creative Commons Attribution 4.0 License}

To Submit Your Article Click Here: Submit Article

DOI: 10.32474/TCEIA.2018.02.000132

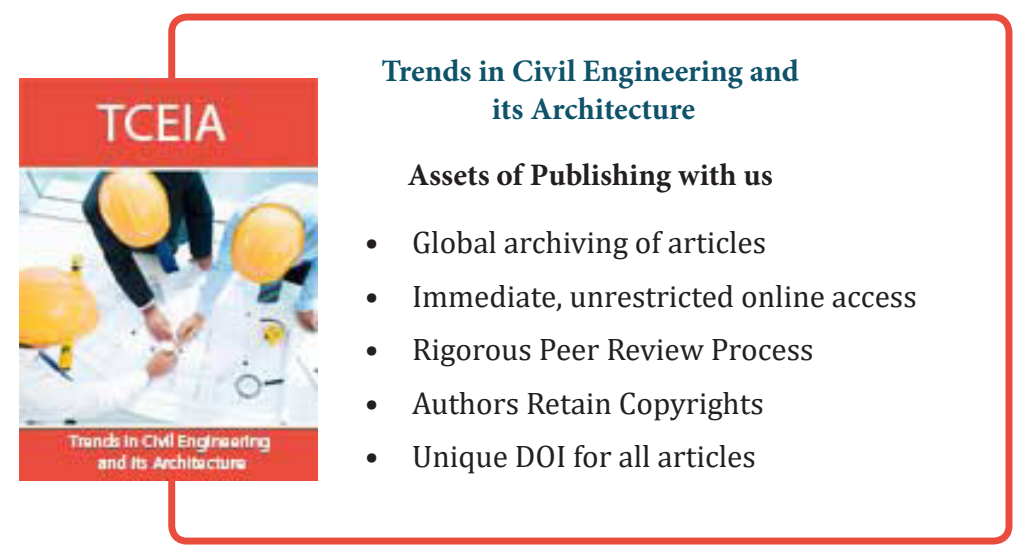

